\begin{tabular}{|l|l|l||}
\hline \multicolumn{2}{|c|}{ PublisherInfo } \\
\hline \hline PublisherName & $:$ & BioMed Central \\
\hline \hline PublisherLocation & $:$ & London \\
\hline \hline PublisherImprintName & $:$ & BioMed Central \\
\hline \hline
\end{tabular}

\title{
Creating protein folds
}

\begin{tabular}{|l|l|l||}
\hline \multicolumn{2}{|c|}{ ArticleInfo } \\
\hline \hline ArticleID & $:$ & 3756 \\
\hline \hline ArticleDOI & $:$ & $10.1186 /$ gb-spotlight-20000901-02 \\
\hline \hline ArticleCitationID & $:$ & spotlight-20000901-02 \\
\hline \hline ArticleSequenceNumber & $:$ & 193 \\
\hline \hline ArticleCategory & $:$ & Research news \\
\hline \hline ArticleFirstPage & $:$ & 1 \\
\hline \hline ArticleLastPage & $:$ & 2 \\
\hline \hline & & RegistrationDate : 2000-09-01 \\
ArticleHistory & $:$ & OnlineDate $: 2000-09-01$ \\
\hline \hline ArticleCopyright & $:$ & BioMed Central Ltd2000 \\
\hline \hline ArticleGrants & $:$ & \\
\hline \hline ArticleContext & $:$ & 130591111 \\
\hline \hline
\end{tabular}




\section{William Wells}

Email: wells@biotext.com

An exon, the basic unit of DNA that gets shuffled around during evolution, has an average coding capacity of 40 amino acids, or roughly half of a small folded protein domain. Exon exchange between homologous proteins can lead to slightly altered proteins, but in the August 29 Proceedings of the National Academy of Sciences Riechmann and Winter ask whether shuffling between unrelated sequences can generate new folds (Proc Natl Acad Sci USA 2000, 97:10068-10073). Their starting material is DNA encoding half of a beta-barrel domain, plus fragmented genomic DNA from Escherichia coli. The fusion products that can fold are selected by their resistance to proteolysis; one of these proteins is significantly more stable than the original intact protein. The genomic segments that survive the selection do not share sequence homology with the starting beta-barrel sequence, although beta structure predominates in the final protein products.

\section{References}

1. DNA shuffling of a family of genes from diverse species accelerates directed evolution.

2. Proceedings of the National Academy of Sciences, [http://www.pnas.org/] 